\title{
JECCE
}

(Journal of Early Childhood Care and Education)

ISSN : 2615-1413 (online)

http://journal2.uad.ac.id/index.php/jecce

\section{The Effect of Assertive Discipline on Early-Aged Children's Gadget Addiction}

\author{
Muniroh Munawar ${ }^{1}$, Nia Lailin Nisfah ${ }^{2}$ \\ PG PAUD, Fakulas IImu Pendidikan, Universitas PGRI Semarang ${ }^{12}$ \\ munirohmunawar@upgris.ac.id ${ }^{1}$
}

Info Artikel

Submitted: $25^{\text {th }}$ August 2019

Accepted: $29^{\text {th }}$ November 2019

Published: $30^{\text {th }}$ December 2019

DOI: 10.26555/jecce.v2i2.1002

Copyright (C) 2019 Universitas

Ahmad Dahlan

\section{Abstrak}

Tujuan dari penelitian ini adalah untuk mengetahui seberapa besar pengaruh penerapan disiplin asertif terhadap kecanduan gadget pada anak usia dini di salah satu TK di Kota Semarang. Jenis penelitian ini merupakan penelitian kuantitatif. Populasi dalam penelitian ini adalah siswa-siswi beserta orangtuanya tahun pelajaran 2018/2019 sejumlah 60 siswa dan 60 orangtua, menggunakan teknik sampling purposive. Penelitian ini memperoleh data melalui angket yang diidi oleh orangtua. Hasil analisis kuesioner diperoleh diperoleh nilai $F=118,649$ dan Sig. $=0,000$. Nilai Sig. jelas lebih kecil dari $\alpha=$ 0,05, maka dapat diputuskan bahwa $\mathrm{H}_{0}$ ditolak. Terdapat pengaruh secara signifikan antara disiplin asertif terhadap kecanduan gadget anak usia dini. Hasil penelitian juga diketahui bahwa $83,8 \%$ pengaruh disiplin asertif terhadap kecanduan gadget. Sementara 16,2\% dari kecanduan gadget dipengaruhi oleh faktor lainnya. Terlihat bahwa disiplin asertif memiliki pengaruh yang sangat dominan terhadap kecanduan gadget.

Kata Kunci : anak usia dini, disiplin tegas, kecanduan gadget Abstract

The study aimed to find out the effect of assertive discipline on the children's gadget addiction in a kindergarten in Semarang City. The present study was categorized into quantitative study. The population of the study was students and their parents in 2018/2019 academic year, there were 60 students and 60 parents, the samples were taken using purposive sampling technique. The data were collected using questionnaire filled by the parents. The analysis result found that the $F$ value was 118,649 and Sig. $=0,000$. Sig. value was lower than $\alpha=0,05$, meaning that $H_{0}$ is rejected. It was found that assertive discipline significantly affects the early-aged children's gadget addiction. The study found that assertive discipline affects gadget addiction by $83.8 \%$. While the other $16.2 \%$ was affected by other factors. It could be seen that assertive discipline possesses dominant effect on gadget addiction.

Keywords : early childhood, discipline assertive, gadget addiction

\section{INTRODUCTION}

In 2018, Digital marketer, a research institution, revealed that there are approximately more than a hundred million smartphone users in Indonesia. Indonesia is the fourth biggest active smartphone users in the world after China, India, and the United States. In Indonesia, there were 143.26 millions of internet users in 2017. Most of the people are smartphone addicts, including children, they even play more smartphone game than watching movies. 
The smartphone and gaming devices excessive use may hamper a child's brain development. Gadget use tends to develop the left-brain, making the right brain left untouched and underdeveloped. The human right brain is associated with concentration, memory storage, and emotion regulation. If the right brain development is hampered, one's attention, memory, and emotion would be in problems.

Parents are the first and the main actor in education. To face the challenges of digital era, parents are required to be technologically literate. In accompanying their children, the parents role are providing instruction on how to use digital media and devices, limiting the usage duration, making a balance with real-life interaction, adjusting the children' needs, selecting application that gives positive impacts, accompanying and improving the family and environment interaction, and checking the children's cyber activity.

Indonesia Child Protection Commission (KPAl) suggests the parents improve their role in providing digital literacy and companion for their children, given that parents are the spearhead of child protection. The parents should be committed to limit the duration of gadget usage and to accompany children when using gadget, preventing addiction, porn, and cybercrime. (www. KOMPAS.com:2017).

The early-aged children's gadget use seize the attention from many parties (Warisyah, 2019). The study from the American Association of Pediatrics (AAP) found that the number of children using gadget almost double, from $38 \%$ to $72 \%$.

CNN Indonesia reports that $70 \%$ of children aged 6 months to 4 years old are allowed to play gadget when their parents doing their work, $65 \%$ of children were given gadget in public place to prevent them from disturbing parent's activities, while before bedtimes, children are left alone with gadget. Then, about $72 \%$ of gadgets the children under 8 years old use are smartphones and tablets (Corey, 2013).

Randers define assertive discipline as noncoercive discipline by choosing basic rule, children are involved to discuss the rule, paying attention to the child's age, then the children are recognized to the logical consequences and intentional negligence (Jazariyah, 2017). Assertive Discipline is also called as Carter's Assertive Discipline Model with some views, namely: all children's behaviors are monitored in a firm-but-not-intimidating manner, the teachers expect good behavior to children, the children get support from parties other than parents such as parents and school principal for their good behavior, children are rewarded due to good behavior, when children violate the rule,the teacher apply logical consequences, carrying out the consequences consistently, delivering verbal and non-verbal communication between teachers and students.

Based on that statement, it could be concluded that assertive discipline is a mean to give children the direction and rule in a right way and proper speech, to introduce them logical consequence and understandable prohibition without giving any punishment, and to give clear instruction and request.

Based on the previous study conducted in a Kindergarten in Semarang City, out of 15 children, $90 \%$ of them loved to use gadget, $75 \%$ of their spare time is used to play gadget, since these children used gadget, $60 \%$ of them loved to be alone, and $35 \%$ of them often rebut. When they were asked to stop playing gadget, $80 \%$ of the children cried. Since the children knew gadget, $70 \%$ of them got angry more easily, $70 \%$ of the children are difficult to be prevented from playing gadget, $60 \%$ of children play gadget just after they arrive home from school, and $90 \%$ of children are unmotivated to study because of gadget playing. 
The result of the interview with the school principal and some of the parents showed that children played gadget at home, and the parents find it difficult to stop them. It is difficult to separate children from the game in their gadget, they are more interested in the game than in the traditional games around them. The parents never forbid them to play gadget, they are left alone to play gadget without noticing their surroundings.

Based on the description and the result of the observation above, it is necessary to conduct a study on "the effect of assertive discipline on Early childhood Gadget Addiction." The study aimed to find out the effect of assertive discipline on the children's gadget addiction in a kindergarten in Semarang City.

\section{METHOD}

The present study employed quantitative method, the data was in the form of number. Statistical analysis was employed to answer the hypotheses of the study. The respondents of the study were 60 parents of kindergarten students in Semarang city. They consisted of 55 mothers and five fathers. The data were analyzed using validity and reliability test. The assumption test consisted of normality, linearity, and hypothesis test. In order to discover the effect of the independent variable $(\mathrm{X})$ on variable $\mathrm{Y}$, the $\mathrm{T}$-test (partial) was conducted using simple linear regression analysis.

\section{RESULT AND DISCUSSION}

The result of the study showed $t$ value $=-10,893$ and sig. $=0,000$. Sig. value was less than $a=$ 0,05 , so it was concluded that the regression coefficient was significant. Thus, it was concluded that there was a negative correlation between assertive discipline and gadget addiction. In other words, the higher the parents' assertive discipline, the lower the children's gadget addiction, and vice versa. Assertive discipline affects gadget addiction by $83.8 \%$. While the other $16.2 \%$ was affected by other factors. It could be seen that assertive discipline possesses dominant effect on gadget addiction.

The present study showed that Assertive discipline significantly affects early-aged children's gadget addiction in a Kindergarten in Semarang City. The finding supported Randers who states that ineffective, coercive discipline and practical discipline are altered by assertive discipline, a discipline with basic strategy for certain situation - for instance, inviting children to discuss the rule, giving them clear instruction and game that suits their age, introducing logical consequence and intentional negligence to them (Jazariyah, 2017). The parents implemented assertive discipline by applying rule along with their children regarding gadget use. Parents limit gadget time, give rewards when children reduce their gadget time and take the children to play outside. The findings from Dewantari and Izzaty showed that assertive training is effective for improving discipline learning (Dewantari \& Izzaty, 2018,2018 ) . In order to improve assertive behavior (e.g, being responsible as a student, being honest, not blaming others, respecting teachers and school regulation), assertive training can be carried out since it helps children to express their anger, it helps children who find themselves difficult to say no, to express affirmation and other positive opinions, and those who think they do not have right to express their opinion (Corey, 2013).

According to Hoyer children in this era know technology better because they are engaged with gadget since the early phase of their life. Data showed that adults absorb $25 \%$ of radiation, while 12 years-old children absorb 50\% of radiation, and 5 years-old children absorb $75 \%$ of radiation. The effect of gadget's electromagnetic wave radiation is not directly visible, however, the parents should monitor their children to select the game that suits their age category wisely, limit 
their gadget time, invite them to socialize with the surroundings, introduce them with local games to develop their cognitive, social, and character. The gadget use is restricted because the result of the study showed that there is a relationship between gadget use and risk of attention deficit and hyperactivity on preschool-aged children (Setianingsih, 2018).

Parents view gadget as "digital babysitter" because children become more serene when using gadget. Parents do not know the adverse influences of gadget such as the children becomes lazy to move their body, resulting in obesity, sub-optimal growth, and eye health. According to Maulida, some indications of gadget addiction on early-aged children are : they refuse to do activities, their discussion topics revolve around gadget, they do not listen to their parent's advice, they become angry when reminded to stop playing gadget, they fail to manage times for gadget and for socialization, they always look for ways to play gadget, and their irregular bedtimes (Warisyah, 2019).

Suardi states that children with gadget addiction are indicated by the followings: (a) lack of focus; (b) become emotional easily; (c) unable to make decision; (d) they are physically big, but do not have mature mental; (e) they cannot communicate properly; (f) they are easily influenced by others; $(\mathrm{g})$ they are less attentive to the surroundings and find it difficult to socialize with others; $(\mathrm{h})$ they do not know about religious and moral values; (i) they do not have self-control; (j) gadget results in bad things, such as bullying, pornography, physical violence, and sexual abuse; (k) lack of creativity; and (I) ess Attentive (Palupi, 2015). Beside that, Wulansari state that the indications of children with gadget addiction are : (a) they do not care with other people when using gadget; (b) they spend their time using gadget; (c) they are angry when reminded to stop playing gadget; (d) they always ask for gadget, and they angry when they do not get it; (e) they prefer to stay at home and refuse to play outdoor; (f) they refuse to do daily activities like shower and sleep (Wulansari, 2017) .

Based on the statements above, it could be concluded that children with gadget addiction are lack creativity, selfish, less attentive, and lack of religious and moral values understanding, difficult to socialize with others, and the surrounding. Besides, They have uncontrolled socioemotional and lack of focus. Another effect of gadget addiction is obesity, it may happen because the children only do minimal movement when playing gadget. Gadget radiation may also jeopardize eye health.

Some research found that the factors affecting the intensity of playing gadget are the parents' lack of communication with children, making them unable to communicate their feeling with the parents or other family members. This condition makes children direct their attention by playing gadget. The lesser the parent's communication and attention to the children, the higher the children's intensity of playing gadget (Novitasari \& Khotimah, 2016; Setianingsih, 2018; Wulandari, 2016).

The finding above is in line with the others who found that one of the parents' way to prevent children from gadget addiction is by monitoring (Siwi \& Safitri, 2019). Without parental control, children would do as they wish, which may adversely affect children. Due to a lack of monitoring, children are free to access online game sites containing violence. Besides, they are also free to watch movies or commercial that does not suit their age through gadget. Online media with violence or porn theme may rapidly harm children's brain development, resulting in gadget addiction. Lack of parental monitoring may result in brain damage due to the high intensity of gadget playing. 
The other study also showed that children's gadget addiction comes from parent's permissive habits (Pebriana, 2017). Parents do not ask for obligation and responsibility from their children. They accept anything their children do. They also do not have good communication with their children. The importance of communication between parents and children is in agreement with the study in Srimpung village, the study found that the parents gave their children gadget to stop their crying (Pebriana, 2017). Parents do not pay attention to the children's growth and development, they never have time to establish good communication with their children, they are not good listener for the children, they prioritize their works over their children, and they leave their children at home unsupervised. With regard to this case, the parents should establish a good communication with their children because interpersonal communication may be seen as one's expression of feeling to another individual. Communication would be well-established when it is done by means of human voice.

One of the parent's and family member's duties are to become a place for children to learn about religious and moral values that form children's character (Ananda, 2017; Purwaningsih, 2012). There is often miscommunication among family members due to bad communication. Based on the case, we conclude that the parents should accompany their children when playing gadget, and communicate with them regarding children's activity using gadget. The parents need to explain the positive and negative effects of excessive gadget playing.

Children's growth and development are established through harmonious relationship between children and parents (Pamungkas et al., 2014). It is pivotal because family plays pivotal role in affecting children's character and forming behavior that suits the religious norms. Gadget's negative effect cannot be left unhandled, it should be prevented by internalizing religious values, directing children without violence, teaching them about goal and their success, and teaching them to manage their time.

Sihura states that gadget is a modern communication device with sophisticated functions (Sihura, 2018). This tiny electronic device holds hundreds of applications simplifying the way people communicate and seek information. Almost everyone has gadget, the worker, adolescent, and even under-aged children around the world, affecting cultural values. Gadget is used for work or daily purposes. It also brings negative impact on adolescent and children with gadget addiction. The present study aimed to describe the parent's role in educating their children regarding gadget use. They play pivotal role in educating them to reduce gadget playing intensity, monitoring them when playing gadget, and providing them logical understanding about the effect of gadget use.

According to Rahmat, effective parenting for children in digital era is authoritative parenting style in family environment (Rahmat, 2018). Family is pivotal because it is one of the trio of education, and the main place for building children's character. The purpose of parenting is to satisfy children's physical and psychological needs. Parents should educate their children in a good manner, without violence. Parents should provide freedom with a proper control to optimize the children's growth and development. Authoritative parenting helps children to be critical against the negative effect of digital era. The parent's role is to educate and to guide their children to use digital media or gadget for positive purposes. This can be done by implementing assertive discipline. The assertive discipline refers to a discipline that teachers children rule and consequences(Aulina, 2013). For instance, when the children violate the predetermined classroom rule, they will face a consequence. They will be reported to the Principal, and their parents will be summoned to school. Assertive 
discipline should be taught since early childhood so that the children understand the rule and logical consequences at school and home.

The recent, communication technology evolution has transformed the communication pattern in a family and slowly crushing the tradition. Thousands of children in this generation are no longer familiar with traditional games such as marbles, hide-and-seek, and other traditional games due to their cyberworld obsession. Their obsession emerges due to today's habit of gadget playing. Today's children, who are raised by technology culture and dependence, do not care about the parent's monitoring process. The new culture alters the communication process between parents and their children. A gadget brings both advantageous and harmful effects for children. Parents should protect their children from addiction by establishing rules, considering children's age, and maintain their eye health due to gadget radiation.

Previous findings mentioned earlier is in agreement with the finding of the present study, that the assertive discipline significantly affects children's gadget addiction. Parents may overcome gadget addiction by implementing assertive discipline, by building a commitment to maintaining good communication with children, by giving rewards to them, introducing them logical consequences without any physical punishment. However, compared to previous studies, the present study holds an advantage because we involve parents in finding out the implementation of assertive discipline and its effect on children's gadget use at home. The parent's or the babysitter's role is important to monitor and to guide children when playing gadgets, for instance, determining the time limit to prevent them from gadget addiction (Ameliola \& Nugraha, 2013).

There are some tricks the parents can apply in accompanying children when using gadget, namely: 1 ) learn to make limit; 2 ) always accompany them when playing gadget, inform them about good and bad content; 3) apply 1821 movement, a gadget-free time for three hours (from 6 pm- 9 $\mathrm{pm}$ ), use it for activities along with children such as communicating and playing together (Alia \& Irwansyah, 2018).

\section{CONCLUSION}

The result of the present study conducted in a kindergarten in Semarang City showed that assertive discipline significantly affects early-aged children's gadget addiction by $83.8 \%$.

\section{REFERENCES}

Alia, T., \& Irwansyah, I. (2018). Pendampingan Orang Tua pada Anak Usia Dini dalam Penggunaan Teknologi Digital [Parent Mentoring of Young Children in the Use of Digital Technology]. Polyglot: Jurnal IImiah, 14(1), 65-78.

Ameliola, S., \& Nugraha, H. D. (2013). Perkembangan media informasi dan teknologi terhadap anak dalam era globalisasi. Prosiding In International Conference On Indonesian Studies" Ethnicity And Globalization.

Ananda, R. (2017). Implementasi nilai-nilai moral dan agama pada anak usia dini. Jurnal Obsesi: Jurnal Pendidikan Anak Usia Dini, 1(1), 19-31.

Aulina, C. N. (2013). Penanaman disiplin pada anak usia dini. PEDAGOGIA: Jurnal Pendidikan, 2(1), 36-49.

Corey, G. (2013). Teori dan Praktek Konseling \& Psikoterapi. PT. Refika Aditama.

Dewantari, T., \& Izzaty, R. E. (2018). Assertive Training On Discipline of Learning in Junior High School. The International Journal of Counseling and Education Vol, 3, 57-62. 
Jazariyah, J. (2017). Pengembangan PAUD Berbasis Keluarga untuk Meningkatkan Ketrampilan Pengasuhan. Al-Hikmah: Indonesian Journal of Early Childhood Islamic Education, 1(1), 1-24.

Novitasari, W., \& Khotimah, N. (2016). Dampak penggunaan gadget terhadap interksi sosial anak usia 5-6 tahun. PAUD Teratai, 5(3).

Palupi, Y. (2015). Digital Parenting Sebagai Wahana Terapi untuk Menyeimbangkan Dunia Digital Dengan Dunia Nyata bagi Anak. 4.

Pamungkas, H. W., Sos, S., \& Si, M. (2014). Interaksi Orang Tua Dengan Anak Dalam Menghadapi Teknologi Komunikasi Internet. Jurnal Tesis PMIS Untan.

Pebriana, P. H. (2017). Analisis Penggunaan Gadget terhadap Kemampuan Interaksi Sosial pada Anak Usia Dini. Jurnal Obsesi: Jurnal Pendidikan Anak Usia Dini, 1(1), 1-11-11. https://doi.org/10.31004/obsesi.v1i1.26

Purwaningsih, E. (2012). Keluarga Dalam Mewujudkan Pendidikan Nilai Sebagai Upaya Mengatasi Degradasi Nilai Moral. Jurnal Pendidikan Sosiologi Dan Humaniora, 1(1).

Rahmat, S. T. (2018). Pola asuh yang efektif untuk mendidik anak di era digital. Jurnal Pendidikan Dan Kebudayaan Missio, 10(2), 143-161.

Setianingsih, S. (2018). Dampak Penggunaan Gadget pada Anak Usia Prasekolah Dapat Meningkatkan Resiko Gangguan Pemusatan Perhatian dan Hiperaktivitas. Gaster, 16(2), 191-205. https://doi.org/10.30787/gaster.v16i2.297

Sihura, F. (2018, November). The Role of Parents 'Generation of Z' to The Early Children in The Using of Gadget. 4th International Conference on Early Childhood Education. Semarang Early Childhood Research and Education Talks (SECRET 2018). https://doi.org/10.2991/secret18.2018.9

Siwi, I. N., \& Safitri, O. R. (2019). The Prevention Of Gadget Addiction And Temper In Children Through Consistency Of Parenting Patterns. ABDIMAS Madani, 1(1).

Warisyah, Y. (2019). Pentingnya pendampingan dialogis orang tua dalam penggunaan gadget pada anak usia dini. Seminar Nasional Pendidikan 2015, O(0), 130-138.

Wulandari, C. M. (2016). Analisis dampak pengunaan teknologi gadget terhadap perilaku siswa di SD Muhammadiyah 4 Batu [PhD Thesis]. University of Muhammadiyah Malang.

Wulansari, N. M. D. (2017). Didiklah Anak Sesuai Zamannya: Mengoptimalkan Potensi Anak Di Era Digital. Visimedia. 